Contributions to the Flora of Cincinnati.

$$
\text { Joseph F. James }
$$

Reprint ex: Jour. Cincinnati Soc. Nat. Hist., July, 1884. 14pp. 

games.

- leontridutions to the Flora of binsiunati. 



\section{CONTRIBUTIONS TO THE FLORA OF CINCINNATI.}

\section{BY JOSFPH F. JAMES.}

Real and referred to the Publishing Committee March 4, 1884.

The following remarks are the result of observations on the plants of the vicinity of Cincinnati, which have been accumulating during the past two or three years. 'The Catalogue of I'lants of Cincinnati, published in 1879, was compiled hastily, and errors unfortunately crept in. Some of these were eorrected, and some additions made in 1s81, by Mr. D. J. James. The present observations embody the results of study of some of our species and genera, and are here presented in the hope of making our flora better known, and of inducing others to study it. Some of the notes have appeared elsewhere, but others are entirely new.

I feel indebted to many persons for information in regard to localities. Most of all, to the late Mr. T. W. Spurlock, one of the most indefatigable students our flora has ever had; to the Misses Mohr, Dr. R. M. Byrnes, Mr. D. L. James, Mr. George B. Twitchell, Mr. C. B. Going, Mr. C. G. Lloyd and Mr. A. P. Morgan, I am also indebted, and desire to thank for their assistance in making the list more complete than it otherwise would have been.

\section{JOSEPH F. JAMES,}

Custodian Cincinnati Society of Natural History.

\section{RANUNCULACEAE.}

7. Anemone Thalictroines, L., has been considered by many writers Thalictrum Anemenoides, Michx. It is still so named in Gray's Manual, and that authority was followed in the catalogue of 1879. Study of the species convineed me that it was more of an Anemone than a Thalictrum, and in Bull. Torr. Bot. Club, vol x., p. 56, I suggested that the old Linnean name be restored, and for the following reasons: It differs essentially from Thalictrum in having an involucre, and agrees in all respeets with Anemone, except that Dr. Gray makes the arbitrary distinction, "achenia-not ribbed." Omit the not and let it read, "Aehenia pointed or tailed, flattened or ribbed," and the generie description of Anemone of Dr. Gray will fit admirably the Rue-Anemone. Since making my note to this effect, I find that Bentham and Hooker have plaeed Syndesmon, Hoffm., under Anemone, though Dr. Gray considered it a subgenus under Thalictrum.

11. Trautvetteria palmata, F. M., was inserted into the catalogue of 1879 , on the authority of Mr. Jea's list published in 1849. No one has 
since, as far as known, found it here, and it should be dropped from the list as not now occurring.

12. Ranunculus aquatilis, L.-Common White water-crowfoot. This was credited to Mr. Clark, but its late finding by Mr. Going places it again certainly on the list. It was found in great abundance near Glendale, 0 .

12 a. Ranunculus yultifidus, Pursh.--Yellow water-crowfoot. This, an entirely new addition to the flora, has been lately found in a small swamp near Glendale, O., close to the other species.

17. Ranunculus REPENS, L., is a most variable species, closely allied to R. bulbosus and R. acris. Muller says (Fertl. of Flowers, p. 76) that bees visit the three species one after another indiscriminately. The species might be crossed in this way and the variability be thus accounted for.

\section{BERBERIDACE Æ.}

31. Caulophyllum thalictroides, Michx.-This is not a common species, only a few stations being known in this vicinity. It is to be sought for on wooded hillsides with a southern exposure, and is easily recognized by the large, glossy green leaves, and rather smal! yellowish green flowers. It is in bloom about May 1.

\section{NY MPHAEACE※.}

34. Nelunbium Luteum, Willd.-The large Yellow Nelumbo, or Water Chinquepin, has been, in all likelihood, exterminated in this vicinity. Lea gives it in his list and Clark in his, though in the latter one, published in 1852 , it was considered as extinct. In early days it doubtless grew in Mill Creek and in the Licking River, but the progress of civilization has driven it away. In the summer of 1876 I found it quite abundant in a pond back of Jeffersonville, Ind. It should be omitted from our list.

\section{PAPAVERACEA.}

37a. Chelidonium majus, L., Celandine.-Found in May, 1881, on Mount Auburn, probably escaped from some garden.

\section{CRUCIFERÆ.}

48a. Cardamine heterophylla, Wood.-An addition to our flora found in the spring of 1882 near Loveland, 0 ., by the writer. Only a single specimen was to be had, but there is no question as to the identification. It differs from $C$. laciniata in having the leaves alternate, and from $C$. 
diphylla in not having the continuous root-stock; the roots consisting of a series of oblong tubers like those of laciniata.

The genera Drntaria and Cardumine have, with good reason, been merged into one by Bentham and Hooker. The differences between them are the habit of growth and the root. In the former genus the leaves are often whorled, or at least are situated near the centre of the stem, and the roots are rhizomes. In the latter genus, the leaves are scattered ou the stem, and the roots are mostly fibrous. The flowers and fruit are almost the same in both.

In a revision of the species of the seetion DENTARIA under CARDAMINE, I have suggested the following arrangement (Bot. Gaz. viii., p. 206):

48. Cardamine dipity lla, Wood.-Stem leaves two, opposite; root-stock long and continuous.

48a. Cardamine heterophylla, Wood.-Stem leaves two to seven, opposite or alternate; root-stock interrupted, of two or three toothed tubers. The forms with more than three leaves are D. maximu, Nuttall.

49. C. Laciniata, Wood.- Stem leaves three, whorled; root-stock nearly as in the last.

Var. multifida, James (D. multifida, Muhl.), is a form of laciniata with finely dissected leaves. I have found the two forms on Lookout Mountain, Tenn., running into each other in impereeptible gradations.

52a. C. Hinsuta, L. Var., sylvatica, Gray. - Both these forms have been found in our vicinity, but from some oversight they have not been previously recorded.

51. C. rotundifolia, Michx.-C. purpurea, Cham. \& Schlecht., was inserted into the eatalogue of 1879 . It was intended to be the var., purpurea, of $C$. rhomboidea, D C. This variety is now considered $C$. rotundifolia, Miehx., as above, though the description given of this species by Gray is not characteristic of our form. It seldom forms runners, and there are numbers of tubers mixed with the fibers of the root as in the rhomboidea.

59a. Hesperis matronalis, L.-Found by Mr. T. W. Spurloek, in Storrs Towuship. The stem is simple and ereet; leaves lanceolate-ovate, denticulate. Flowers purple; blooms from June to A ugust.

65a. AlYssum Lescuril, Gray, given in a former list, should be omitted. There was a mistake in the identification.

66. Camelina Sativa, C'rantz.-This is given in Lea's eatalogue. It has 
not been recognized of late as far as is known. It is an introduced plant, with small yellow flowers and lanceolate and arrow-shaped leaves (Gray). It should probably be omitted from the list.

\section{CARYOPHYLLACE压。}

82. Silene nivea, D C. - This species was first found in our locality by Miss Kate Peachey, along the Little Miami River, near Loveland, Ohio. The pateh was a small one, but well established, though subject to overflow by the river, and liable to be buried out of sight under deposits of mud. The flowers are quite large, white, and at a hasty glance are liable to be mistaken for S. stellata, Ait., from which they differ, however, in having the petals cleft only, instead of fringed; and the leaves are opposite instead of whorled

S6a. Silene noctiflora, L.-Recorded by Mr. C. G. Lloyd as found at Crittenden, Ky. Ẹscaped from cultivation.

PORTULACACE压.

98. Claytonia Virginica, L.-Mr. Davis L. James has made some interesting observations on the fertilization of this plant, which are here inserted from his notes.

"If the flower of Claytonia Virginica be observed soon after it opens for the first time, the stamens will be found standing ereet and around the pistil, the lobes of the style closely pressed together, and none of the stigmatic surface exposed. The anthers are extrorse. The stamens remain erect the first day and the style lengthens slightly. The second day the stamens are mature, they begin to shed their pollen, and are bent towards the petals. The style has been further lengthened.

"On the third day in the life of the flower the filaments are bent outwards and the anthers are now closely pressed on the petals; the style has elongated, its lobes are recurved and the stigmatic surface is exposed. Flowers with reflexed stamens and a mature style, and with erect stamens and undeveloped style, are both found on one plant, the former always below the latter in the raceme. The inseet observed in the work of fertilization is a small bee.

"Mr. Meehan thinks that the pollen which is shed upon the petals by the ripening stamens is brought into contact with the stigma when the flower closes at night. But as the flower droops as it closes, the pollen would more likely fall to the ground. I have seen the pollen shed upon the petals in but one case, and that was in a plant brought into the house and placed in damp sand. Claytonia is quite fertile with us, not one out 
of many hundred plants showing imperfect capsules. Heterostylism was not observed, all the speeimens being alike."

The two species of Claytonia given by Gray, vi\%: C. Virginicu and $C$. Carmliniana are hard to distinguish. The only difference seems in the leaves. In the first they are linear, and the second "spatulate-oblong or oval-lanceolate" (Gray). As one seems to predominate in the West and South, and the other is a more northern form, it seems probable that the Caroliniana is more of a geographical variety than a distinct species. C. Caroliniana scems a misnomer, for it is the more northern form of the two.

\section{MALVACER.}

107. NAPAEA DIOIC, Clayt, was inserted in the catalogue on the authority of Mr. Spurloek, who formerly found it in this vicinity. Is it has not been seen for many years it would be wise to consider it extinct in our loeality.

109a. Gossypicm herbacerm, L (Cotton Plant). - An introduced plant which has been found growing in the sweepings of freight ears in the yards of the O. \& M. R. R., Storrs Township, on the Ohio River bank. The flower is quite large, yellow, turning with age to a reddish-brown; the calyx is subtended by an involucre of three bracts, and the fruit forms a solid boll. It is uncertain if it ripens here. The species ean be considered as only doubtfully established.

109b. Hibiscus Trioxum, L.-Found at Loveland by Miss K. Peachey, is an escape from cultivation, and may be considered as naturalized.

110. Hibiscus militaris, Cav.-Was found during the summer of 1883 by Mr. George B. Twitehell, growing wild near Delhi, on the C. I. St. L. \& C. R. R. This is the first time it has been recorded since Mr. Clark's list was published in 1852 , and it thus re-establishes an old species.

\section{GERANIACEE.}

116. Floerkea proserpinacoines, Willd, is an ineonspicuous plant, but has been found in great abundanee near Ludlow Grove by Mr. Spurlock. It is a species liable to be overlooked, because of its manner and place of growth; the loealities where it is found are damp or swampy.

VITACE.E.

130. Ampelopsis gunquerolia, Miehx., is considered by our latest authorities to be Vitss Quineuerolis, Bentham of Hooker. 
SAPINDACE E.

133. Aesculus flava, Aiton. - Sweet Buckeye. A peculiar feature of this species was noted in a tree growing near Loveland, $O$. The lowest branches started from the trunk at least twenty feet from the base, and then drooping suddenly eame down to within about six feet of the ground, and then spread out horizontally. Nearly all the branches seemed to have the same mode of growth.

ANACARDIACEA.

141. Rhus venenata, D.C., is given in Clark's Catalogue. I have never found it here, nor do I know of its having been found lately. It should be omitted from the list.

\section{LEGUMINOSA.}

143. Trifolidm pratense, L. - At the meeting of the Agricultural Congress at Montreal in August, 1882, Prof. W. J. Beal read a paper on the variations to be noticed in the red clover (Trifo'ium pratense). $\mathrm{He}$ spoke of the varied habit of growth, it being sometimes upright and sometimes spreading; called attention to the presence or absence of pubescence; to the presence or absence of spots on the leaves; to the variation in the number and color of the seeds, and said that he generally found the heads to be sessile. He further thought that by selection the varieties might be greatly improved. The variation which Prof. Beal did not notice so prominently has been noticed this year (1884) to be very common. In many instances I have found the heads of flowers to be distinctly stalked, sometimes these stalks being as much as two inches long.

In our botanies the distinctions between Trifolium pratense and $T$. medium are these: In the former the heads are sessile and the leaflets are spotted; in the latter the heads are stalked and the leares are unspotted; while a still further difference is given by Hooker in Student's Flora of the British Isles; this is, that the pods of the T. pratense open by the top falling off, and those of the medium have a longitudinal dehiscence. None of these characters seem to hold good. In some speoimens the leaves are spotted and the heads are stalked; in others the heads are sessile and the leaves are not spotted; while all the pods I have examined have a longitudinal dehiscence. Dr. Gray in the Manual says the one species is too near the other, and it would seem from the facts now known that it would be wise to unite the two species under the name of $T$. pratense.

149a. Medicago Sativa, L. Alfalfa, Lucerne.-A plant with three parted leaves and blue flowers, extensively cultivated in many places as 
food for cattle. It has been introduced in some localities here, has eseaped and is well estalished. I large patch can be found near Newton Station on the I. M. R. R., and another on the I. C. \& I. R. R. ('Twitehell.)

153. Astragalus CoOperi, Gray.-This was found during the summer of 1853 by Dr. R. M. Byrnes, on the hills west of the city and near Price's Hill Incline. It was given in the eatalogrue on the atuthority of Mr. Lea, and its rediscovery is interesting. It differs from our common 1. Canadensis in having the few flowers more loosely arranged in the spike, and in the pod being one instead of two celled.

176a. Cassia occinentalis, 1, - Though a native further south, this species has been found occasionally by Mr. Spurlock, growing in company with Gossypium, near Sedamsville. Only eight specimens were found, growing in such a situation that they were liable to be covered over or swept away at any time. They dicl not flower until very late, and only one or two perfected fruit. Another specimen was found by Mr. Going at the Stock Yards (C. W. \& B. R. R.), but was killed by the frost before it bloomed.

177. Cassia Tora, L. (C. obtusifolia, L.) - A few speeimens were found by Mr. Spurlock on Bank Lick, back of Covington, also by Mr. Gioing at the Stock Yards with C. occidentalis, $L$.

178a. Cassia sictitans, L.-Found growing on the Ohio River bank by Mr. Spurlock.

As all the five species given in Gray's Manual have been, at times, found in this vicinity, the ehief character of each is here appended.

176. Cassia Marylandica, L.- Tall, with spike of large yellow flowers; six to nine pairs of leaflets.

176a. Cassia occidentalis, L. - Flowers smaller than the preceding; four to six pairs of aeute leaflets; long, linear pods.

177. Cassia 'Tora, I. (C. obtusifulia, L.) - leaflets, two or three pairs. obtuse; pods six inches long.

178. Cassia Chamaforista, L.-Stems spreading; flower, large. axillary; leaflets, ten to fifteen pairs, slightly sensitive.

178a. Cassia nictitans, L.-Flowers very smill; leaflets, ten to twenty pairs and sensitive, closing almost instantly.

The first and fourth of these are eommon in this vicinity, but the other three have as yet only an uncertain tenure, and can be considered only as waifs and strays. 
ROSACE.S.

193a. Potentilla Recta, Willd.-This species has been found only within a few days growing in Liden Park by Miss Sarah C. Stubbs. It is a strong growing species, two or three feet high, with five to seven cut. serrate leaflets, and large light yellow flowers. It is by far the handsomest Potentilla yet found here.

HA MAMELACEN.

219a. Liquidamar Strraciflua, L.-Sweet Gum. A quite hardy tree, planted by the late Dr John A. Warder, at North Bend, O. It has been observed in the woods near Mt. Healthy by Mr. Morgan. It grows abundantly throughout Kentucky.

HALORAGEA.

220. MYriophylum.-There are four species of this genus given in the catalogue on the authority of Mr. Clark. None have, as far as is known, been identitied here of late years. They should be looked for in ponds and pools. An investigation of the caual basin near the Work-house, and of Ross Lake, would perhaps add to our knowledge of them. Other water plants, too, are likely to be discovered in these places.

ONAGRACEA.

232a Jussi a leptocarpa, Nuttall.--This species is a strictly southern one, and was found on a floating $\log$ at the mouth of the Licking River by Mr. Lloyd. The following is the description, taken from Chapman's Flora of the Southern States, page 140:

"Hairy; stem erect, at length much branched ; leaves lanceolate, acute; flowers small; calyx lobes mostly six, as long as the petals; capsule linear, cylindrical, nuch longer than the pedicel. Marshes, Florida and westward, June, September. Stem, two fect to five feet high; capsule, one and a half inches long, slightly curved."

It is to be hoped that this species will be found again. At present, however, it can not be claimed as belonging to our permanent flora.

UMBELLIFERA.

243. Caucalis anthriscus, Huds.--First discovered by Mr. C. G. Lloyd at Mt. Isookout, it has since been found by others, and is becoming thoroughly naturalized. It is supposed that it was first introduced with some imported cattle of Mr. Kilgour's. It cannot be considered a desirable addition to our flora. As the species is not noticed in any of our 
botanieal manuals the description is inserted below. Filorit of British Islands, pp. 179-180.)

(Hooker's Students

"Caucalis, I.-Annual, hispid herbs; leaves, 1-3 pinnate; umbels compound, terminal or leaf-opposed, usually of few rays. sometimes bracts few or none; bracteoles more numerous; flowers, white or purplish, polygamous, outer often rayed; erlyx teeth acute or nonc; petals often unequal, the larger notehed, point inflexed ; disk lobes, thiek, conical; fruit, ovoid or oblong, constricted at the commissure; earpophore undivided or ¿-fid; carpels sub-terete, ridges with one or two series of spines; vittae solitary in each secondary ridge; seed deeply grooved ventrally.

"C. Axtrisiscrs, Hudson.- - Jeaves, 1-2 pinnate; leaflets, broad; umbels, terminal, compound; bracts, 4-6; spines of fruit, incurved, not hooked. Hispid more or less; stem erect, branched, solid, striate; hairs reflexed; leaflets many, close set, one-fourth to one-third inches, pinnatifid or lobed; umbels, 5-12-rayed; bracts, small subulate; flowers, minnute, white or pink, outer pedi celed, fertile; fruit, one-eighth ineh, ovoid; styles short, straight."

244. Heracleum Lanatim, Michx. - Credited to Mr. Lea's catalogue, but found this year at Cumminsville by Mr. Going. It has a very large umbel of greenish-white flowers, very large leaves and is very rank and coarse in growth.

25:3. C'icuta bulbifera, L.--Credited to Mr. Clark in the eatalogue; was found near Ludlow Grove during 1883 by Mr. Spurlock. It grows abundintly in wet places. It is easily distinguished from C. maculata, by its linear leaflets, and the presence of numerous bulblets in the axils of the leaves.

\section{ARALIACE.F.}

261. Aralia spinosa, L., Hereules Club, ete.-This is not a common plant in this vicinity, but is a striking one in appearance. It grows fifteen or twenty feet high, with the slender trunk covered with prickles. The large compound leaves spread out in a cluster near the top of the stem.

\section{COMPOSIT F.}

310a. Aster longibolous, Lam.-Very common in places along the Little Niami River at Loveland, 0.

339. Xanthius spinosum, L.-Quite common along roads back of Covington, but never yet found on this side of the river.

347. LEPACHYS is now considered a synonym of RUDBECKIA. 
362a. Coreopsis trichosperma, Michx.--Found by the Misses Mohr near Burnet Woods; afterwards by Mr. Spurlock on the canal near the Work house. This is a very western station, as it is mostly confined to the coast. It is easily recognized by its finely dissected leaves and bright yellow flowers.

370a. Matricaria discoidea, DC.-This has been found near Loveland, $O$., in one spot, and was doubtless introduced with some plants from California. It has previously been recorded from only one or two localities in the eastern section of the country.

371. Leucanthemun vulgare, Lam, Ox-eye Daisy.-Is now referred back by Bentham \& Hooker to the old name of Chrysanthemum Leucanthemum, L.

392. Lappa officinalis, Allione, is now called Arctium Major, L.

392a. Cichorium Intyous, L.--Cichory. Found by the Misses Mohr on Elm Street Hill, apparently well established. The flowers are quite large, bright blue, leaves minute and inconspicuous.

LOBELIACE屟.

410. Lobelia spicata, Lam.-This has been credited to Clark's catalogue, but three or four specimens were found last year by the writer near Branch Hill, $\mathrm{O}$.

\section{CAMPANULACEæ.}

412. Specularia Americana, Morgan (Campanula Americana,L.).This common species is, I believe, a true Specularia. While all the genuine Campanulas have bell-shaped, drooping, pediceled flowers, the species of Specularia have rotate, erect and sessile flowers. These last points are found in the $C$. Americana. In Hooker's Students' Flora of the BritIslands, Specularia is a sub-genus under Campanula. In the Genera Plantarum they are kept distinct. As Mr. A. P. Morgan first suggested the change here given, he is credited with the new name.

412a. Campanula Rapunculoides, L. - Found by the Misses Mohr on Elm Street Hill. Escaped and naturalized.

\section{ERICACE}

415. Monotropa uniflora, L.-A large bunch of plants of this species was exhibited before this Society on October 3, 1882. An examination of the cluster to see if any indication of parasitism could be found, revealed no connection between its mass of roots and those of the trees among which it grew. The mass resembled more the mycelium of a fun- 
gus than true roots, and the conclusion reached was, that at that period of its life, at least, the plant drew its nourishment from the decaying vegetable matter among which it grew. Whether during a previous period the roots were connected with those of trees could not be ascertained, but all appearanees were against such connection. (See Vick's Monthly Magazine, vol. v., p. 330-332.)

BIGNONIACELE.

430a. Catalia specrosa, lingelm.-First brought into notice by the late Dr. J. A. Warder, and by him considered a valuable tree for building and other purposes. The following is the description from Botanical Gazette, vol. r., p. 1:

"A middle-sized tree, with grayish brown, much eracked or furrowed, at last slightly flaky bark, and light yellowish gray wood; leaves litrge, truncated or more or less eordate at base, slightly acuminate, soft, downy on the under side, inodorous; flowers in large and loose panicles; tube of the corolla conical, longer than wide, its lower part scarcely protracted; upper lip before its expansion longer than the other lobes and enreloping them; lower lobe bi-lobed; inside of the corolla slightly marked at the throat with red-brown lines, and with two yellow bands at the commissures of the lowest with the lateral lobes; stamens and style as long as the tube, pod terete, strongly furrowed; wings of the seed about as long as the seed itself, rounded at the ends and split into a broad coma."

\section{LABIATEA.}

771a. Trichostema nenotonta, L.-Found during 1883 on the Ohio River bank. A very much branched herb, with small flowers, and similar in habit of growth to Isanthus caeruleus, Michx.

CONVOLULACEA.

5:33. Convolveus Arvensis, L.-Found by Mr. Spurlock and Mr. Going.

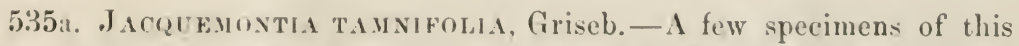
species, native much further south, were found by Mr. (C. B. Going at the Stock Yards on the C. W. \& B. R. R. The description is appended. The plant ean be eonsidered as only a waif, and may or may not be found again.

"JACQremonta. Choisey. - A rather small genus, tropical or subtropical, mostly with the aspect of Convolvulus.

"J. тамsifola, Griesb.-Erect or at length twining, fulvous-hirsute; ront annual; leaves cordate and ovate, long petioled, pinnately veiny; 
peduncles elongated, eapitately many flowered; glomerate cluster involucrate with foliaceous bracts; sepals subulate linear, ferruginous-hirsute, 5 lines long, nearly equaling the violet corolla. Cult. and waste grounds, from South Carolina and Arkansas southward." (Gray Syn. Flo. N. Am., vol. ii., part 1, p. 214.) Chapman under Ipomoea tamnifolia, adds, "Capsule depressed, somewhat four-sided."

SOLANACEF.

540a. Physalis Philadelphica, Lam.-Quite common at Loveland, O. Identified during the past summer (1883).

546. Datura neteloides, D C.-This seems to be the species formerly given in the catalogue as "D. metel, Locke." It is cultivated in old gardens and may have escaped to roadsides in some places. The principal characters of the species are as follows: Puberulent or pubescent; leaves ovate, entire or repand-toothed; corolla six to eight inches long, white or tinged with violet, sweet scented. Native along streams in Texas to Arizona and California. Chapman considers metel as a good species, but it is probably only a synonym.

546a. Nicotiana Tabacun, L.-As this species is being largely cultivated in this vicinity it is likely to escape and be found along roadsides. It is easily known by the exceedingly large leaves and tall spike of tubular, pinkish flowers.

\section{EUPHORBIACE压.}

616a. Euphorbia CYPARISSiAs, L.-Growing abundantly on a private place near Loveland, 0 , and escaped from cultivation.

\section{LEMNACEE.}

678. LEMNA MINOR, L.-Given in the catalogue on the authority of Mr. Clark. It has recently (June 1884) been rediscovered at Cumminsville by Mr. Going.

\section{NAIADACE E.}

684. Zannichellia Palustris, L. - This species credited to Mr. Lea has been lately found by Mr. Going in the same locality as Lemna minor. There are, doubtless, many species of Potamogeton in our streams also.

TYPHACE E.

682a. Sparganium simplex, Hudson.-Chester Park. Dr. R. M. Byrnes.

ORCHIDACE.E.

696. Spiranthes cernua, Richard.-A single specimen of this was 
found September 17, 18\$2, by Mr. D. L. James near Loveland. It had not before been identified here since Clark's list was published.

\section{IRIDACE $\mathrm{A}$.}

707. Iris versicolor, L.-This was found this year at Chester Park, by Mr. Going. Before credited to Mr. Clark, it is thus rediscovered. Dr. R. M. Byrnes has found it in Mount Lookout woods and at Batavia Junction, on the L. M. R. R.

\section{CY PERACEF.}

783. Carex crinita, Lam.-This was credited to Lea's catalogue, but has lately been found by Mr. Going near Gilendale. The Carices of this vicinity have not been very industriously collected, and a little attentiou would doubtless add many species to the list.

\section{GRAMINE̊E.}

S46a. Lolium perfane, L. - This species, a new one to the flora, was found in Avondale by Mr. D. L. James.

851a. Avena striata, Michx.-A new species to the flora, and found by Dr. R. M. Byrnes.

854a. Pinalaris Canariensis, L. (Canary Grass.)-Found frequently about houses and on rubbish heaps.

858a. Panicum virgatum, L.-Was found by Mr. spurlock near Sedamsville. It grows from three to five feet high, and has a very long panicle of flowers.

859. Panicum hatifoluim, L.-D. L. James.

861. Panicum diciotomum, Muhl. -D. L. James.

862. Panicum depauperatem, Muhl.-D. L. James.

865. Cexcinus tribuloides, L.-Hedgehog or bur-grass. "A vile weed" (Gray). Introduced and growing abundantly along the O.\& M. R. R., near Riverside. Easily recognized by the spiny fruit.

\section{EQUISETACEA.}

87t. Equlsetum hymate, L.-Miss Marie Mohr.

\section{FILICES.}

875. Potyponum Incanim, L. - This species was found in a single locality a few years since by Drs. Byrnes and Langdon, and has lately been observed by the writer. Specimens were collected from a partially dead tree near Batavia Junction, on the L. M. R. R. It is very rare in this region. 
OPHIOGLOSSACEA.

S97. Boytrychiun ternatua, Swartz.-Mr. S. T. Carley furnishes the following information regarding this species: The frond makes its appearance in July, and the fertile part soon matures; the sterile portion persists till within a month of the time for the new frond to appear. In winter it is copper red, and in the spring changes to the original green of the young frond.

\section{CHARACEÆ.}

S99a. Chara coronata, Ziz. - This appeared in a tub of water-lilies near Loveland. The interesting genus, of which there are many species in the United States, has not been studied in our section. The canal basin near the Work-house, Ross Lake and similar places, will probably yield several species. 




